\title{
Radīf-e Mīrzā 'Abdollāh barāye tār va setār. Tehrān, Māhūr, 1385/2006, 335 p. (transcriptions et texte en anglais) + 59 p. (persan).
}

\section{Sāsān Fāṭemī}

\section{(2) OpenEdition}

\section{Journals}

Édition électronique

URL : http://journals.openedition.org/abstractairanica/33712

DOI : 10.4000/abstractairanica.33712

ISSN : 1961-960X

Éditeur :

CNRS (UMR 7528 Mondes iraniens et indiens), Éditions de l'IFRI

\section{Édition imprimée}

Date de publication : 15 mai 2008

ISSN : 0240-8910

\section{Référence électronique}

Sāsān Fātemī, « Radîf-e Mīrzā 'Abdollāh barāye tār va setār. Tehrān, Māhūr, 1385/2006, 335 p.

(transcriptions et texte en anglais) + 59 p. (persan). », Abstracta Iranica [En ligne], Volume 29 | 2008, document 438, mis en ligne le 15 septembre 2008, consulté le 26 septembre 2020. URL : http:// journals.openedition.org/abstractairanica/33712; DOI : https://doi.org/10.4000/abstractairanica. 33712

Ce document a été généré automatiquement le 26 septembre 2020.

Tous droits réservés 


\section{Radīf-e Mìrzā 'Abdollāh barāye tār va setār. Tehrān, Māhūr, 1385/2006, 335 p. (transcriptions et texte en anglais) +59 p. (persan).}

\section{Sāsān Fāțemī}

C'est la réédition d'un livre qui n'a pas encore perdu son importance. La première édition avait paru en 1991 sous le nom de Radîf-e sāzì-ye mūsīqi-ye sonnatī-ye İrān, radîf-e tār va setār-e Mīrzā 'Abdollāh be revāyat-e Nūr-'Alī Borūmand (Le répertoire-modèle de la musique iranienne, radif de târ et de setâr de Mirzâ 'Abdollâh, version de Nur-Ali Borumand), Tehrān, Sorūšs. L'A. a révisé les transcriptions en séparant nettement les phrases mélodiques les unes des autres. Il a également révisé ses introductions en les adaptant aux apports nouveaux des recherches récentes. Ses petites remarques sur différentes possibilités de l'accordage et sur différents aspects de chaque dastgāh et chaque $\bar{a} v \bar{a} z$, qu'on ne trouve pas dans la première édition, sont très utiles. Il y a annexé également quelques pièces des grands maîtres de la musique iranienne, comme Davāmī, Karīmī, Forūtan et Hormozì.

\section{INDEX}

Thèmes : 17.1.Musique 
AUTEURS

SĀSĀN FĀTEMIĪ

Université de Téhéran 